\title{
Ocular Findings of Cryptococcal Meningitis in HIV-AIDS Patients
}

\author{
Miriam Díaz, Bety Yáñez \\ Ophthalmology Department, Dos de Mayo Hospital, Lima, Peru \\ Email: byanez@hotmail.com
}

How to cite this paper: Díaz, M. and Yáñez, B. (2018) Ocular Findings of Cryptococcal Meningitis in HIV-AIDS Patients. Open Access Library Journal, 5: e4818. https://doi.org/10.4236/oalib.1104818

Received: August 1, 2018

Accepted: August 24, 2018

Published: August 27, 2018

Copyright $\odot 2018$ by authors and Open Access Library Inc.

This work is licensed under the Creative Commons Attribution International License (CC BY 4.0).

http://creativecommons.org/licenses/by/4.0/

\begin{abstract}
Purpose: To describe the ophthalmological characteristics, clinical course and visual prognosis of HIV-AIDS patients with cryptococcal meningitis. Methods: Retrospective study conducted in HIV-AIDS diagnosed outpatients treated at Dos de Mayo Hospital, from 2004 to 2014. Descriptive statistics were obtained for age, gender, associated diseases, CD4 T cell counts, antiretroviral therapy (ART), cryptococcal meningitis symptoms, relapses and visual complaints data. Diagnosis was based in CSF analysis, Chinese dye and culture. CSF opening pressure was recorded. Descriptive statistics were performed. Results: 18 cases were studied. 16 men and 2 women. The range of age was 24 - 51 and median 33 years. Three patients had been treated with ART. Tuberculosis was the most frequent associated disease IN 5 cases (27.8\%). Cryptoccocal meningitis relapses were present in 5 (27.8\%). CD4 count below 50 was the most prevalent in $11(61 \%)$. Thirteen had ocular symptoms, low visual acuity was present in the half of cases and diplopia in 2 (11.1\%). 13 (72.2\%) coursed with headache. In eleven cases, the CSF opening pressures had been reported, and the range was $18-350 \mathrm{~mm} \mathrm{H}_{2} \mathrm{O}$, mean 67-6. CSF culture was obtained in 11 patients, it was positive in 7 (38.9\%). Indian ink was positive in 16 (88.9\%). Conclusion: There was no blindness related with cryptococcal meningitis despite the higher values of CSF opening pressure reported.
\end{abstract}

\section{Subject Areas \\ Ophthalmology}

\section{Keywords}

Cryptococcal Meningitis, HIV, AIDS, Ocular Findings, Blindness

\section{Introduction}

The most common life-threatening fungal pathogen that affects patients with 
HIV-AIDS is Cryptococcus neoformans [1] [2]. It is the most important cause of fungal meningoencephalitis in Latin America, with $85 \%$ of cases caused by ${ }^{\circ} \mathrm{C}$. neoformans [3] [4]; 80\% are associated with HIV infection [5] [6]. Although the number of cases is less with the advent of antiretroviral therapy (ART), it remains a significant cause of mortality in these patients.

Ocular involvement with visual changes is reported in near one-third of HIV-AIDS infected patients. Papilledema is the most common ocular involvement due to cryptococcal infection in HIV-positive [7] [8]. Several manifestations can occur such as oculomotor palsies, diplopia, nistagmus, sixth nerve palsy, opthalmolplegia and ptosis [9] [10]. Intraocular manifestations include choroiditis, chorioretinitis, vitritis, endophthalmitis, and neuroretinitis [11] [12].

Vision loss may be due to yeasts infiltration of optic nerve, increased intracranial pressure, inflammatory compression of the optic nerve, adhesive arachnoiditis, amphotericin B toxicity, cerebral vasculitis among other things [13] [14] [15].

We describe the ophthalmic characteristics, clinical course and visual prognosis of HIV-AIDS patients with cryptococcal meningitis.

\section{Materials and Methods}

This was a retrospective study conducted in HIV-AIDS diagnosed outpatients treated at Dos de Mayo Hospital, Peru between April 2004 and December 2014. The author obtained the approval from the Institutional Ethics Committee before the study began.

Demographics, HIV infection history, CD4 T cell counts, plasma HIV viral load, ART therapy, associated diseases, cryptococcal meningitis clinical symptoms (headache, papilledema), relapses and visual complaints data were obtained.

Diagnosis of cryptococcal meningitis was based in CSF analysis, Chinese dye and culture. CSF opening pressure was recorded.

All these variables were collected in a SPSS 22 data base and descriptive statistics were performed.

\section{Results}

2527 HIV- AIDS outpatients were evaluated. 23 had cryptococcal meningitis diagnosis but only 18 were included in the study because they had a full clinical record. They were 16 men and 2 women. The range of age was 24 - 51 and median 33 years. Three patients had been treated with ART. Tuberculosis (TB) was the most frequent associated disease with 5 cases $(27.7 \%)$, followed by cytomegalovirus retinitis (CMVR), 2 cases (11.1\%), one patient had TB, CMVR and Kaposi Sarcoma. Cryptoccocal meningitis relapses were present in 5 (27.8\%). Two patients had two and three episodes of relapses respectively. CD4 T cells count below 50 was the most prevalent in 11 (61\%). Table 1 shows the demograpic characteristics of patients. 
Table 1. Demographics characteristics.

\begin{tabular}{ccc}
\hline & N & $\%$ \\
\hline Age (Media) & 33 & \\
Sex & & 89 \\
Male & 16 & 11 \\
Female & 2 & \\
HIV disease time (Media) & 24.4 months & 61 \\
CD4 $<50$ & 11 & 17 \\
ART & 3 & 33 \\
Associated diseases & & 11 \\
TB & 6 & 28 \\
CMV & 2 & \\
\hline Cryptococcal meningitis relapses & 5 & \\
\hline
\end{tabular}

Thirteen had ocular symptoms, low visual acuity was present in the half of cases and diplopia in 2 (11.1\%). Moreover, $13(72.2 \%)$ of them coursed with headache and $2(11.1 \%)$ with papilledema. In eleven cases; CSF opening pressure had been reported, the range was $18-350 \mathrm{cc} \mathrm{H}_{2} \mathrm{O}$, the mean 67.6. CSF culture was obtained in 11 patients. It was positive in 7 (38.9\%). Indian ink was positive in 16 (88.9\%). Only three patients had a Computed Tomography (CT) result, cerebral oedema, cerebritis and normal CT respectively. Table 2 summarizes the main clinical symptoms, signs and diagnostic studies.

Blindness was reported in 4 eyes. One patient had bilateral blindness caused by trauma and the other two had unilateral blindness, CMVR and trauma respectively. Only five patients had follow-up. The longest follow-up time was 120 months, the median 20.67 months.

\section{Discussion}

Cryptococcal meningitis, is one of the leading opportunistic infections in the developing world. Latin America is the third global region with most cases with 54,400 estimated cryptococcal meningitis cases annually in 2008 [2]. Its prevalence varies from $6 \%$ to $10 \%$ in Brazil [16], more than $15 \%$ in Africa [17] and 5.6\% in Peru [18].

It is estimated that $5 \%$, of these patients would have lost their eyesight and spent the last six months of their lives either partially or totally blind [19].

The affected population had an average of 33 years, similar to that reported by Canelo in Peru [20], Monaco in Argentina [21] and Ordoñez in Colombia [22].

A low CD4 cell count is the main predictor of risk of cryptococcal meningoencephalitis [23]. In this study $61 \%$ had a cell count below 50 cells/microL. Signs and symptoms of presentation may vary according to The host with headache more frequently observed in HIV AIDS patients [10], 72.2\% of our patients coursed with headache and $2(11.1 \%)$ with papilledema. 
Table 2. Clinical symptoms, signs and diagnostic studies.

\begin{tabular}{ccc}
\hline & N & $\%$ \\
\hline Low vision & 7 & 39 \\
Diplopia & 2 & 11 \\
Cephalea & 13 & 72 \\
Papiledema & 2 & 11 \\
Indian ink positive & 16 & 89 \\
Culture positive & 7 & 39 \\
CSF opening pressure $>20 \mathrm{~mm} / \mathrm{H}_{2} \mathrm{O}$ & 10 & 56 \\
\hline
\end{tabular}

The worst course of headache, papilledema, visual and hearing loss and increased mortality of this opportunistic complication increases in patients with high CSF opening pressure [8] [24], Indian ink positive anda higher number of relapses [10]. In this study mean CSF opening pressure was high $67.6 \mathrm{cc}_{2} \mathrm{O}$, and $45 \%$ of them had a CSF opening pressure $>35 \mathrm{cc} \mathrm{H}_{2} \mathrm{O}$, higher values compared with previous studies [8] [25]; cryptococcal meningitis relapses in 5 (27.8\%) and Indian ink was positive in 16 (88.9\%).

The etiology of visual complications associated with cryptococcal meningitis remains unclear. Possible explanations for visual loss include elevated cerebrospinal fluid (CSF) pressure, direct infiltration of the optic nerve or optic tracts by the fungus, inflammatory compression of the optic nerve, adhesive arachnoiditis [13] [14] [15].

In this study there was no blindness related with cryptococcal meningitis but for other causes, trauma and CMVR. This finding is not according with studies carry on undeveloped areas [19] perhaps explained this because the follow-up was very short in most patients.

Despite the fact that free ART is available in Peru since 2004, which would lead us to think about the reduction of opportunistic infections, the reduced number of patients in this group that received it (17\%) highlights the socio-economic and cultural barriers to access ART and fight against the reduction of HIV-AIDS and its complications.

Cryptococcal meningitis is a serious threat for HIV-AIDS patients and justifies further studies to know the reality of each population.

\section{Conclusion}

The ophthalmologic findings were described in 18 patients with HIV-AIDS peruvian patients with cryptococcal meningitis. $61 \%$ had $\mathrm{CD} 4 \mathrm{~T}$ cells count below 50 cells/microL and $\mathrm{TB}$ was the most frequent associated disease (27\%). Only $17 \%$ received ART. Despite the high values of CSF opening pressure, no cases of blindness caused by cryptococcal meningitis were found.

\section{Aknowledgements}

The authors wish to thank the assistance provided by Norma Pletikosic Silva in 
revising the text.

\section{Conflicts of Interest}

The authors declare no conflicts of interest regarding the publication of this paper.

\section{References}

[1] Mirza, S.A., Phelan, M., Rimland, D., Graviss, E., Hamill, R., et al. (2003) The Changing Epidemiology of Cryptococcosis: An Update from Population Based Active Surveillance in 2 Large Metropolitan Areas, 1992-2000. Clinical Infectious Diseases, 36, 789-794. https://doi.org/10.1086/368091

[2] Park, B.J., Wannemuehler, K.A., Marston, B.J., Govender, N., Pappas, P.G., et al. (2009) Estimation of the Current Global Burden of Cryptococcal Meningitis among Persons Living with HIV/AIDS. AIDS, 23, 525-530.

[3] Olivares, L.R., Martínez, K.M., Cruz, R.M., Rivera, M.A., Meyer, W., et al. (2009) Genotyping of Mexican Cryptococcus neoformans and C. gattii Isolates by PCR-Fingerprinting. Medical Mycology, 47, 713-721. https://doi.org/10.3109/13693780802559031

[4] Vidal, J.E., de Oliveira, P.A.C., Dauar, R.F. and Boulware, D.R. (2013) Strategies to Reduce Mortality and Morbidity Due to AIDS-Related Cryptococcal Meningitis in Latin America. Brazilian Journal of Infectious Diseases, 17, 353-362.

[5] Quinet-Leiman, B.C. and Jorge-Koifman, R. (2009) Official Information Systems for Cryptococcal Meningitis, State of Rio de Janeiro, Southeastern Brazil. Revista de Saúde Pública, 43, 1-4.

[6] Cunha Colombo, E.R., Mora, D.J. and Silva-Vergara, M.L. (2011) Immune Reconstitution Inflammatory Syndrome (IRIS) Associated with Cryptococcus neoformans Infection in AIDS Patients. Mycoses, 54, e178-e182. https://doi.org/10.1111/j.1439-0507.2010.01870.x

[7] Johnston, S.R., Corbett, E.L., Foster, O., Ash, S. and Cohen, J. (1992) Raised Intracranial Pressure and Visual Complications in AIDS Patients with Cryptococcal Meningitis. Journal of Infection, 24, 185-189. https://doi.org/10.1016/0163-4453(92)92954-H

[8] Graybill, J.R., Sobel, J., Saag, M., van Der Horst, C., Powderly, W., et al. (2000) Diagnosis and the NIAID Mycoses Study Group and AIDS Cooperative Treatment Groups. Clinical Infectious Diseases, 30, 47-54.

[9] Kestelyn, P., Taelman, H., Bogaerts, J., Kagame, A., Abdel Aziz, M., et al. (1993) Ophthalmic Manifestations of Infections with Cryptococcus neoformans in Patients with the Acquired Immunodeficiency Syndrome. American Journal of Ophthalmology, 116, 721-727. https://doi.org/10.1016/S0002-9394(14)73472-5

[10] Antinori, S. (2013) New Insights into HIV/AIDS-Associated Cryptococcosis. ISRN AIDS, 2013, Article ID: 471363. https://doi.org/10.1155/2013/471363

[11] Babu, K., Murthy, K.R. and Rajagopalan, N. (2008) Primary Bilateral Multifocal Choroiditis as an Initial Manifestation of Disseminated Cryptococcosis in a HIV-Positive Patient. Ocular Immunology and Inflammation, 16, 191-193.

[12] Denning, D.W., Armstrong, R.W., Fishman, M. and Stevens, D.A. (1991) Endophtalmitis in a Patient with Disseminated Cryptoccocosis and AIDS Who Was Treated with Itraconazole. Clinical Infectious Diseases, 13, 1126-1130.

https://doi.org/10.1093/clinids/13.6.1126 
[13] Rex, J.H., Larsen, R.A., Dismukes, W.E., Cloud, G.A. and Bennett, J.E. (1993) Catastrophic Visual Loss Due to Cryptococcus neoformans Meningitis. Medicine, 72, 207-224. https://doi.org/10.1097/00005792-199307000-00001

[14] Corti, M., Solari, R., Cangelosi, D., Domínguez, C., Yampolsky, C., et al. (2010) Sudden Blindness Due to Bilateral Optic Neuropathy Associated with Cryptococcal Meningitis in an AIDS Patient. Revista Iberoamericana de Micología, 27, 207-209. https://doi.org/10.1016/j.riam.2010.09.002

[15] Duggan, J. and Walls, H.M. (2012) Ocular Complications of Cryptococcal Meningitis in Patients with HIV: Report of Two Cases and Review of the Literature. Journal of the International Association of Providers of AIDS Care (JIAPAC), 11, 283-288. https://doi.org/10.1177/1545109712448537

[16] Pappalardo, M.C. and Melhem, M.S. (2003) Cryptococcosis: A Review of the Brazilian Experience for the Disease. Revista do Instituto de Medicina Tropical de São Paulo, 45, 299-305. https://doi.org/10.1590/S0036-46652003000600001

[17] Békondi, C., Bernede, C., Passone, N., Minssart, P., Kamalo, C., et al. (2006) Primary and Opportunistic Pathogens Associated with Meningitis in Adults in Bangui, Central African Republic, in Relation to Human Immunodeficiency Virus Serostatus. International Journal of Infectious Diseases, 10, 387-395. https://doi.org/10.1016/j.ijid.2005.07.004

[18] Campos, P. and Rojas, R. (1994) Complicaciones infecciosas del sistema nervioso central en el SIDA. In: Sanchez, J., Mazzoti, G., Cuellar, L., Campos, P. and Gottuzzo, E., Eds., SIDA, epidemiología diagnóstico, tratamiento y control de la infección VIH SIDA, OMS/OPS MINSA, Perú, 141-149.

[19] Kestelyn, P.G. and Cunningham Jr., E.T. (2001) HIV/AIDS and Blindness. Bulletin of the World Health Organization, 79, 208-213.

[20] Canelo, C., Navarro, A., Guevara, M., Urcia, F., Zurita, S., et al. (1999) Determinación de la Variedad de Cepas de Cryptococcus Neoformans aisladas de pacientes con SIDA. Revista Peruana de Medicina Experimental y Salud Publica, 16, 44-47.

[21] Mónaco, L.S. and Tamayo, A.(2008) Criptococcosis en pacientes SIDA: Estudio de casos en el Hospital Paroissien en el período 1996-2007. Revista Argentina de Microbiología, 40, 218-221.

[22] Ordóñez, N. and Castañeda, E. (1994) Serotipificación de aislamientos clínicos y del medio ambiente de Cryptococcus neoformans en Colombia. Biomedica, 14, 131-139. https://doi.org/10.7705/biomedica.v14i3.2096

[23] Jarvis, J.N. and Harrison, T.S. (2007) HIV-Associated Cryptococcal Meningitis. AIDS, 21, 2119-2129. https://doi.org/10.1097/QAD.0b013e3282a4a64d

[24] Lee, S.C., Dickson, D.W. and Casadevall, A. (1996) Pathology of Cryptococcal Meningoencephalitis: Analysis of 27 Patients with Pathogenetic Implications. Human Pathology, 27, 839-847. https://doi.org/10.1016/S0046-8177(96)90459-1

[25] Bicanic, T., Brouwer, A.E., Meintjes, G., Rebe, K., Limmathurotsakul, D., et al. (2009) Relationship of Cerebrospinal Fluid Pressure, Fungal Burden and Outcome in Patients with Cryptococcal Meningitis Undergoing Serial Lumbar Punctures. AIDS, 23, 701-706. 